\title{
RAZVOJ HRVATSKOG TRANSFORMACIJSKOG SUSTAVA KAO PREDUVJET PROVEDBE CILJEVA ODRŽIVOG RAZVOJA
}

\author{
Miljenko Cimeša i Andreja Pavlović
}

Zaostroška 1, 10000 Zagreb e-mail:mcimesa@gmail.com

\begin{abstract}
Sažetak
Ciljevi održivog razvoja (COR-ovi) predstavljaju vrlo ambiciozan plan i program razvoja ljudskog društva. Upozorenje Meduvladinog panela o klimatskim promjenama iz 2018. o nužnosti smanjivanja emisija $\mathrm{CO}_{2}$ za 45\% do 2030. i postizanja ugljične neutralnosti do 2050., ukazuje na to da je vrijeme za njihovo ostvarivanje ograničeno. Istraživačko pitanje u fokusu ovog rada odnosi se na ocjenu spremnosti Hrvatske za provedbu COR-ova. U radu se testira teza da Hrvatska nije spremna za provedbu COR-ova. Provedba $C O R$-ova zahtijevat će ostvarivanje transformativnih promjena na svim razinama i u svim segmentima hrvatskog drustva. Cilj je rada poticanje rasprava i aktivnosti usmjerenih prema razvoju strukture (i kulture) suradnje kao pretpostavke za ostvarivanje COR-ova u Hrvatskoj. U radu se koristi konceptualna analiza djela iz razlicitih znanstvenih područja, analizu radova o strukturi i funkcioniranju „nordijskog modela" te analiza radova o stanju u Hrvatskoj. U interpretaciji nalaza koristena su oruda sustavnog mišljenja koje omogućuje sagledavanje najdubljih uzroka postojećih problema. Istraživanje je potvrdilo polaznu tezu o tome kako Hrvatska nije spremna na provedbu COR-ova. Preliminarne ocjene stanja u Hrvatskoj ukazale su na nepostojanje općeprihvaćene zajedničke vizije drustva, kao i odsustvo prosocijalnog ponašanja u svim segmentima i na svim razinama drustva. U takvim okolnostima provedba COR-ova u Hrvatskoj, u zadanim vremenskim okvirima, doista zahtijeva pokretanje transformativnih promjena. To je najvažnija moralna obveza postojeće generacije lidera prema budućim generacijama.
\end{abstract}

Ključne riječi: ciljevi održivog razvoja, transformativne promjene, nordijski model, sustavno mišljenje, kultura suradnje

\section{UVOD}

Na Općoj skupštini UN-a 25. rujna. 2015. usvojena je rezolucija „Mijenjajmo svoj svijet, Agenda za održivi razvoj“, odnosno Agenda 2030 (UN, 2020a), u kojoj su artikulirani Ciljevi održivog razvoja (COR). U analizi izvedivosti COR-ova (Randers i sur., 2019) ukazuje se na konflikt između društveno-ekonomskih (ciljevi 1-12) i ekoloških ciljeva (ciljevi 13-15). Naime, rješavanje problema siromaštva, gladi, opskrbe vodom i energijom, osiguranja zdravlja i obrazovanja i sl. rezultira povećanjem potrošnje resursa, te otežava ostvarivanje ekoloških ciljeva. Stoga će, po našem mišljenju, presudnu ulogu imati provedba ciljeva 16 (promicati razvoj miroljubivih i uključivih društava za održivi 
razvoj, osigurati pristup pravosuđu za sve, i izgraditi učinkovite, odgovorne i uključive institucije na svim razinama) i 17 (revitalizirati globalno partnerstvo za održivi razvoj). Riječju, razvoj kulture i strukture suradnje.

Agenda 2030 predstavlja ambiciozni program i plan djelovanja koji bi trebao osigurati dostojanstven život i zadovoljenje osnovnih potreba čovječanstva - unutar biofizičkih granica. Upozorenje Međuvladinog panela o klimatskim promjenama (IPCC, 2018) o nužnosti smanjivanja emisija $\mathrm{CO}_{2}$ za $45 \%$ do 2030. i postizanja ugljične neutralnosti do 2050. ukazuje na to da je vrijeme za ostvarivanje COR-ova ograničeno.

Istraživačko pitanje u fokusu rada odnosi se na ocjenu spremnosti Hrvatske za provedbu COR-ova. U radu će se testirati teza da Hrvatska nije spremna za provedbu COR-ova. $\mathrm{U}$ radu se polazi od pretpostavke kako provedba COR-ova, kao odgovor na ključne izazove s kojima je suočeno suvremeno društvo (pr. klimatske promjene, uništavanje biološke raznolikosti, pretjerana upotreba prirodnih resursa ${ }^{1}$, ekonomske nejednakosti, siromaštvo, glad, globalna pandemija izazvana virusom COVID-19, terorizam, migracije i sl.) zahtijeva ostvarivanje transformacijskih promjena. Naime, netom spomenuti ključni izazovi predstavljaju simptome problema. Stoga je za sagledavanje njihovih najdubljih izvora nužno korištenje oruđa sustavnog mišljenja ${ }^{2}$ model ledenjaka (vidi Sliku 1) (Scharmer i Kaeaufer 2013:3).

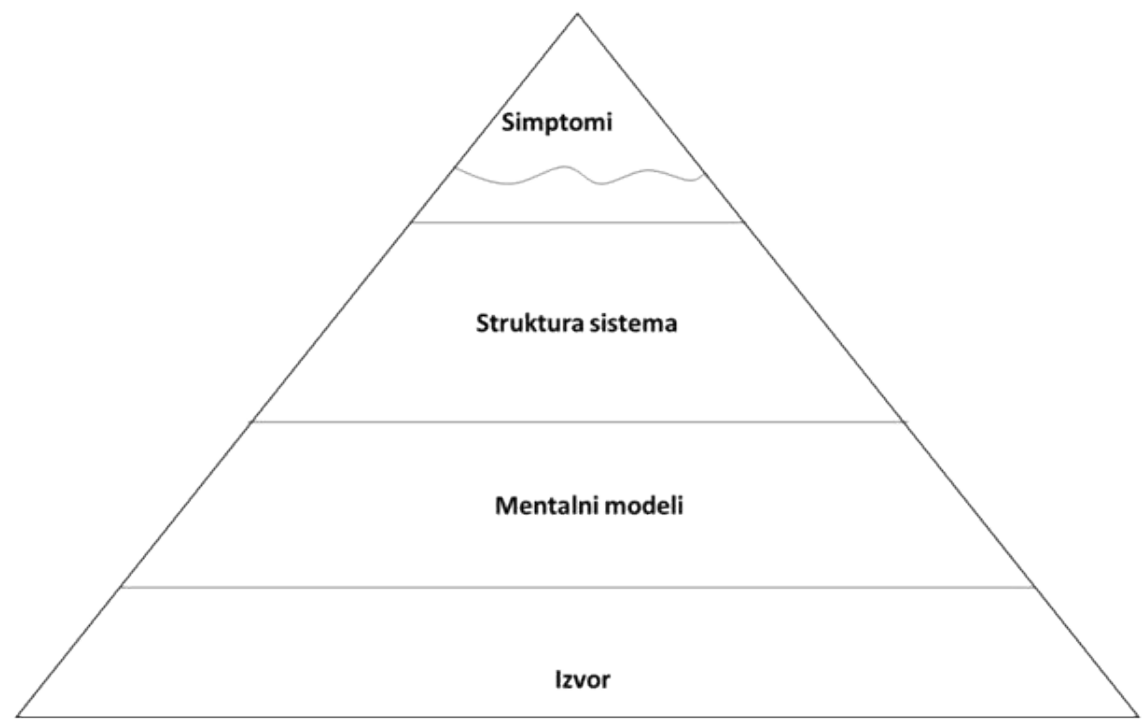

Slika 1. Model ledenjaka

\footnotetext{
1 Što rezultira time da globalni „ekološki otisak“ (mjera potrošnje prirodnih resursa u odnosu na sposobnost ekosustava da ih proizvedu) iznosi 1,75 (GFN, 2020). To znači da čovječanstvo troši 1,75 puta više prirodnih resursa u odnosu na biofizičke kapacitete planete.

2 Sustavno je mišljenje pojmovni okvir, korpus znanja i oruđa koja omogućuju razumijevanje i mijenjanje sustava (Senge, 2000:20).
} 
Iz Slike 1 proizlazi kako simptomi problema nastaju iz strukture i funkcioniranja sustava. Struktura i funkcioniranje sustava odražava dominantne mentalne modele (način razmišljanja, paradigmu, sustav vrijednosti), kao i izvor, tj. razinu svijesti. Sukladno tome transformativne promjene obuhvaćaju promjene svijesti i načina razmišljanja. Promjene svijesti bi trebale ići u smjeru evolucije ${ }^{3}$ od ego-svijestí $i^{4}$ prema eko-svijesti ${ }^{5}$. Promjene načina razmišljanja koje proizlaze iz nove svijesti, među ostalima, odnose se na definiranje i usvajanje nove političko-ekonomske paradigme. Na temelju nove svijesti i novog načina razmišljanja bit će nužno pristupiti analizi i redizajnu sustava na makro (politički, ekonomski, socijalni, obrazovni) i mikro razini (poduzeća). Primjerice, redizajnu političkog sustava od predstavničke demokracije prema "dubokoj demokraciji“ (Freinacht, 2017); ekonomije od sustava zasnovanog na profitu i rastu, prema „ekonomiji dobrobiti“ (engl. wellbeing economy); energetike od sustava koji se oslanja na neobnovljive, prema sustavu temeljenom na obnovljivim izvorima energije itd. Redizajn sustava na postojećoj razini svijesti i načina razmišljanja ne omogućuje dovoljno duboke promjene. U skladu s tim takvi pristupi nude „lažna rješenja“ (Wildfire, 2020) koja mogu privremeno ublažiti simptome, ne otklanjajući stvarne uzroke problema. Nenamjeravane posljedice korištenja takvih „rješenja“ obično se pojavljuju nakon izvjesnog vremena izazivajući povratak simptoma problema (ponekad u težem obliku).

Cilj je rada poticanje rasprava i aktivnosti usmjerenih prema razvoju strukture (i kulture) suradnje kao pretpostavke za ostvarivanje COR-ova u Hrvatskoj.

$\mathrm{U}$ radu se koristi konceptualna analiza radova iz područja psihologije, politologije, sociologije, filozofije i ekonomije o modelu razvoja društva i ostvarivanja transformativnih promjena. Drugi dio metodologije odnosi se na analizu radova o strukturi i funkcioniranju „nordijskog modela“, a treći na analizu radova o stanju u Hrvatskoj. U interpretaciji nalaza korištena su oruđa sustavnog mišljenja koja omogućuju sagledavanje najdubljih uzroka postojećih simptoma problema.

\section{HRVATSKI TRANSFORMACIJSKI SUSTAV}

Prijedlog za uspostavljanje transformacijskog sustava proizlazi iz uvida o najdubljim uzrocima postojećih izazova (vidi Sliku 1), kao i spoznaje o tome kako je riječ o novoj vrsti izazova. S tim u vezi Kahane (2004:31) navodi kako je riječ o „teškim problemima“ (engl. tough problems) koje karakteriziraju tri vrste kompleksnosti: dinamička (što znači da neki problem ima velik broj varijabli na strani uzroka i posljedica, koje međusobno djeluju, a koje je zbog brojnosti i njihove odvojenosti u prostoru i vremenu teško prepo-

\footnotetext{
3 To je ključna poruka knjige Scharmer i Kaeaufer (2013).

4 Sebična svijest, svijest koja vodi računa samo o kratkoročnim i osobnim interesima.

5 Nesebična svijest, svijest koja vodi računa ne samo o osobnim interesima i interesima svoje skupine, nego i o dugoročnim interesima cjeline, odnosno društvene zajednice na lokalnoj, nacionalnoj ili globalnoj razini. 6 Slika 6 predstavlja primjer dinamičke kompleksnosti.
} 
znati); društvena ${ }^{7}$ (zbog razlika u vrijednostima, postavkama i ciljevima, dionici probleme $s$ kojima su suočeni interpretiraju na različite načine te predlažu različita rješenja); generativna ${ }^{8}$ (sustav se mijenja na nove i nepredvidljive načine generirajući izazove bez presedana). Prisustvo dinamičke kompleksnosti zahtijeva korištenje sustavnog načina razmišljanja. Zbog društvene kompleksnosti nužno je uključivanje relevantnih dionika u proces suodlučivanja, dok postojanje generativne kompleksnosti znači da ne postoje trajna rješenja, nego je nužan razvoj transformacijskog sustava koji će stalno iznova kreirati rješenja. Ideju o dizajnu transformacijskog sustava, premda drugačije strukturiranu, u novije doba zagovaraju i znanstvenici okupljeni oko SDG Transfomations Foruma (2020).

Hrvatski transformacijski sustav (HTS) trebao bi biti „ugniježđen sustav“ (engl. nested system) koji obuhvaća nacionalnu, regionalnu i lokalnu razinu teritorijalne organizacije društva, te poduzeća i pojedince. S druge bi strane, HTS trebao biti dio transformacijskih sustava EU-a i UN-a. Izrada Dobrovoljnih nacionalnih pregleda (engl. Voluntary National Review), (UN, 2020b) putem kojih države ocjenjuju napredak u ostvarivanju COR-ova predstavlja početak razvoja globalnog transformacijskog sustava.

Naredni argumenti u prilog razvoja transformacijskog sustava kao „ugniježđenog sustava“ proizlaze iz istraživanja Ostrom (2014), dobitnice Nobelove nagrade za ekonomiju 2009. koja navodi kako klimatske promjene uzrokuju aktivnosti pojedinaca, obitelji, poduzeća i drugih čimbenika. Stoga ona zaključuje kako je nužna promjena u obrascima svakodnevnog ponašanja pojedinog čimbenika. Riječju, nužno je kolektivno djelovanje velikog broja čimbenika, pozicioniranih na različitim razinama hijerarhije društvenih sustava. Međutim, potreba kolektivnog djelovanja obično rezultira nastankom problema ,švercanja“ (engl. free riding). To znači da mnogi ne daju doprinos ostvarivanju zajedničkih interesa, ali nastoje koristiti plodove rada drugih. Rješenje tog problema Ostrom vidi u ključnim principima dizajna sustava upravljanja (opširnije o tome u nastavku).

Besprijekorno funkcioniranje ugniježđenih sustava zahtijeva razvoj mehanizama vertikalnog i horizontalnog usklađivanja. Prvi mehanizam proizlazi iz primjene teorije selekcije na više razina (engl. multilevel selection theory). Da bi neka društvena skupina funkcionirala kao cjelina, njezini članovi moraju si uzajamno pomagati (Wilson i Wilson 2007). Ipak, takva nesebična ponašanja pojedinaca u korist drugih članova ili skupine u cjelini, rijetko unapređuju njihove relativne pozicije unutar skupine: plodove njihovih napora najčešće prisvajaju sebični članovi skupine. Rješenje ovog problema sastoji se u tome da se selekcija odvija na više razina hijerarhije: individualnoj i grupnoj. Riječju, premda sebični pojedinci mogu nadvladati altruiste unutar skupine, altruistične skupine pobjeduju sebične skupine. To znači da je suradnja unutar skupine i razvoj altruističkih skupina u (dugoročnom) osobnom interesu svakog člana.

\footnotetext{
7 Pregovori o klimatskim promjenama, tj. sukobi između razvijenih i nerazvijenih zemalja ukazuju na ovu dimenziju kompleksnosti.

8 Situaciju nakon globalne pandemije mnogi, s pravom, nazivaju „izazovom bez presedana“.
} 
Naredni mehanizam usklađivanja zasniva se na primjeni ključnih principa dizajna (engl. core design principles) sustava upravljanja (Ostrom, 2015:90) poolom zajedničkih resursa (pr. projekt navodnjavanja), klimatskim promjenama ili razvojem društva. $S$ tim u vezi Atkins i suradnici (2019:35-44) predlažu novu, unaprijeđenu verziju Ostromovih principa, te su ih preimenovali u "principe suradnje“:

- Zajednički identitet $i$ svrha. Skupina najbolje funkcionira kad članovi zajednički kreiraju, shvate i prihvate zajedničku svrhu, kad im ta svrha omogućuje stvaranje osjećaja zajedničkog identiteta i pripadnosti, a zatim usmjerava i koordinira njihovo djelovanje.

- Pravedna raspodjela doprinosa i koristi. Većina ljudi ima snažan osjećaj pravednosti. Percipirana pravednost ključna je za suradnju - kako unutar, tako i između skupina.

- Pravedno i inkluzivno odlučivanje. Članovi skupine trebaju imati mogućnost sudjelovanja u procesu donošenja odluka koje na njih utječu.

- Nadzor provedbe dogovorenih odluka. Iskustva uspješnih skupina pokazuju da one biraju promatrače iz svojih redova i sustav sam sebe nadzire.

- Postupne reakcije na ponašanje članova skupine. Pozitivna ponašanja rezultiraju stimulacijama za promjenu, a negativna mjerama destimulacije. Mjere stimulacija i destimulacija su u početku blage, a zatim sve snažnije. Time se članovi sustava potiču na pridržavanje dogovorenih odluka uz postupni rast troškova za prekršitelja čime se osigurava minimalizacija potencijalnih negativnih učinaka na osjećaj zajedničkog identiteta.

- Brzo i pošteno rješavanje sukoba. Tijekom vremena članovi skupine različito interpretiraju problemske situacije što dovodi do međusobnih sukoba. Stoga je u sustav bitno ugraditi mehanizme brzog i pravednog rješavanja sukoba.

- Ovlaštenja za samostalno upravljanje (u skladu s prethodnih šest principa). Ključni preduvjet uspješnosti skupina predstavlja stvaranje okruženja koje osigurava njihovu samostalnost. Institucije više razine ne mogu dovoditi u pitanje pravo članova nižih razina da razviju vlastita pravila.

- Suradnički odnosi s drugim skupinama (u skladu s prethodnih sedam principa). Želimo li izgraditi sustave suradnje, skupina treba prakticirati prethodnih sedam principa ne samo u rješavanju internih problema, nego i u odnosima s drugim skupinama. Na taj se način uspostavljaju identični principi ponašanja na svim razinama socijalno-kulturne hijerarhije.

U nastavku rada, u fokusu pozornosti bit će nacionalna razina HTS-a ${ }^{9}$. Prvi korak u dizajnu nekog sustava sastoji se u promatranju i analizi postojećih praksi. S obzirom na to da je riječ o provedbi COR-ova, tada pretraživanje podataka o državama koje imaju najbolje rezultate unutar tog područja logično predstavlja prvi korak.

Prema najnovijem Izvješću o održivom razvoju (Sustainable Development Report 2019) nordijske zemlje ostvaruju relativno najbolje rezultate u provedbi ciljeva održivog razvo-

9 Fokusiranost na nacionalnu razinu proizlazi iz ograničenja vezanih uz raspoloživi prostor. 
ja i to prema sljedećem redoslijedu: Danska (1), Švedska (2), Finska (3), Norveška (8) (Sachs i sur., 2019:20). Ključna poruka ovog izvješća je to kako „nijedna zemlja nije na putu ostvarenja svih 17 ciljeva" (Sachs i sur., 2019:X). Najveće razlike u učinku su u ciljevima 12 (odgovorna potrošnja i proizvodnja), 13 (odgovor na klimatske promjene), 14 (očuvanje vodenog svijeta) i 15 (očuvanje života na kopnu). Prema Izvješću o razini sreće (engl. World Happiness Report) (Helliwell i sur., 2019:24) rang lista izgleda ovako: Finska (1), Danska (2), Norveška (3) i Švedska (7). Slično, prema Indeksu društvenog razvoja (engl. Human Development Indicators and Indices) (UNDP, 2018:22) na prvom je mjestu Norveška, dok su Švedska, Danska i Finska na 7., 11. i 15. mjestu. Prema Globalnom izvješću o konkurentnosti (engl. The Global Competitiveness Report) (Schwab, 2019:xiii) nordijske zemlje također su u svjetskom vrhu: Švedska je na 8. mjestu, Danska na 10., Finska na 11., a Norveška na 17. mjestu.

$\mathrm{Na}$ izbor nordijskih zemalja kao referentnih jedinica utjecala je ocjena švicarskog filozofa Freinachta (2017:64) kako nordijske zemlje predstavljaju „najprogresivnija društva u svijetu", kao i ocjene evolucijskih biologa Wilsona i Hessena (2018:29) kako su one svoj razvoj zasnivale na teoriji višerazinske selekcije i ključnih principa dizajna sustava.

\section{NORDIJSKI MODEL}

Sintagma "nordijski model ${ }^{“ 10}$ posljednjih godina privlači veliku pozornost stručne i opće javnosti. O modelu su objavljene brojne knjige, članci, analize i izvještaji ${ }^{11}$. Model koji je ovdje prikazan predstavlja "generičku verziju“ od koje svaka nordijska zemlja polazi u dizajniranju svojih specifičnih sustava i politika razvoja. Prema Witoszek i Midtum (2018:2) nordijske zemlje prošle su dvije faze modernizacije. Tehno-ekonomska faza modernizacije, zahvaljujući tehnološkom razvoju i industrijskoj revoluciji rezultirala je rastom produktivnosti i životnog standarda, ali je izazvala društvene probleme (ekonomske i društvene nejednakosti). Faza društvene modernizacije (u vidu razvoja države blagostanja), omogućila je rješavanje društvenih problema. U ovom trenutku nordijske zemlje (kao i svijet u cjelini) suočene su s izazovom ostvarivanja ekomodernizacije, $t \mathrm{t}$. usklađivanja modela razvoja društva s biofizičkim, planetarnim granicama ${ }^{12}$.

Suvremena društva predstavljaju kompleksne društvene sustave koji obuhvaćaju brojne podsustave. Za prezentaciju „nordijskog modela“ Witoszek i Midtum (2018:6) koriste sljedeći grafički prikaz (Slika 2).

Normativno-kulturalno područje obuhvaća obrazovanje i znanost te medije. Društveno-političko područje odnosi se na zakonodavnu, izvršnu i sudsku granu vlasti te javnu upravu. Tehno-ekonomsko područje obuhvaća inovacijski i monetarni sustav, financije,

10 Riječ je o modelu društvenog razvoja koji se, pod utjecajem specifične kulture, tijekom vremena razvijao u nordijskim zemljama (Švedska, Norveška, Danska).

11 Pretraživanje interneta pokazuje da o ovoj temi postoji 220 milijuna objava (pretraživanje je obavljeno 10.05.2020.).

12 Tek provedba svih triju modernizacija omogućuje ostvarivanje COR-ova. 
industriju, poljoprivredu, trgovinu, tržište rada... Socijalno područje obuhvaća mirovinski i zdravstveni sustav, sustav socijalne skrbi, kao i sustav socijalne sigurnosti vezano uz funkcioniranje tržišta rada.

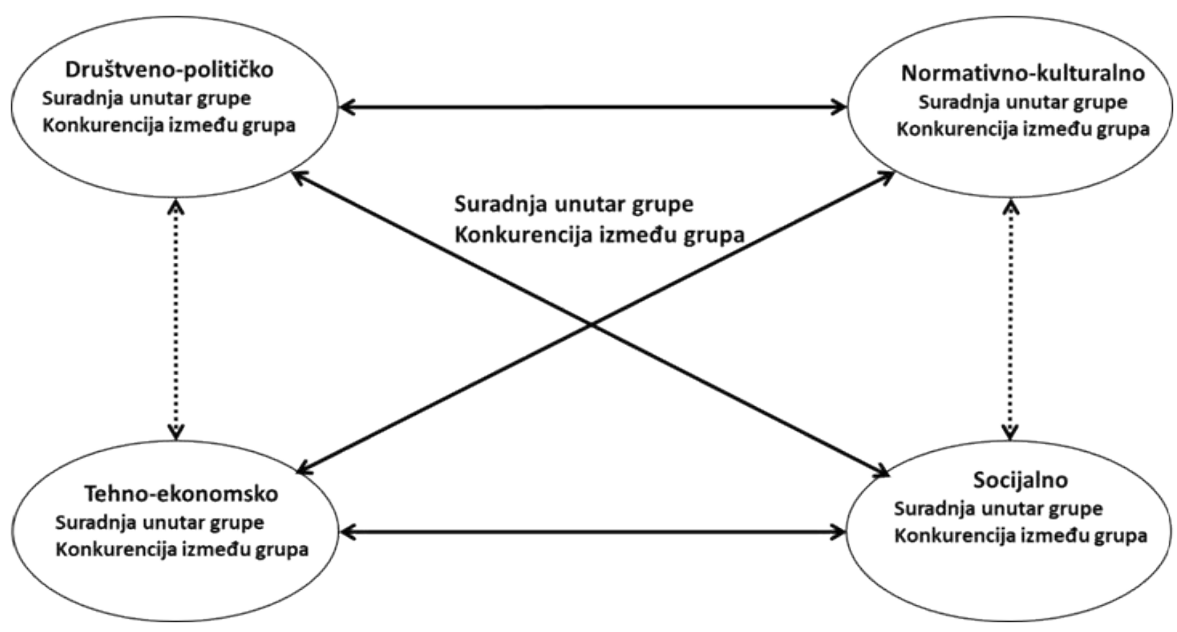

Slika 2. Nordijski model (prema Witoszek i Midtum, 2018:6, uz nadopunu autora)

$\mathrm{Na}$ Slici 2 vidljive su interakcije između pojedinih područja: a) normativno-kulturalni $\Leftrightarrow$ društveno-politički; b) normativno-kulturalni $\Leftrightarrow$ ekonomski; c) društveno-politički $\Leftrightarrow$ socijalni; d) ekonomski $\Leftrightarrow$ socijalni. Pored navedenih, u analizu je, prema našem mišljenju, bilo nužno uključiti i sljedeće interakcije: e) društveno-politički $\Leftrightarrow$ ekonomski; f) normativno-kulturalni $\Leftrightarrow$ socijalni. Stoga su na prikazu modela dodane i te poveznice ${ }^{13}$.

U skladu s teorijom višerazinske selekcije, na Slici 2 istaknut je aksiom o nužnosti suradnje u okviru skupine (tj. razvoj altruističnih skupina) i konkurencije između skupina (gdje altruistične skupine pobjeđuju sebične skupine) ${ }^{14}$. S tim u vezi Witoszek i Sørensen (2018:37) navode kako se suvremena nordijska društva zasnivaju na kulturnim obrascima kršćanskog prosvjetiteljstva koji su se postupno razvijali od 16. stoljeća. Skupina kř̌ćanskih svećenika propovijedala je ideale dobrote te vrijednosti poštovanja, suradnje, pragmatičnog racionalizma, prihvaćanja umjerenosti, kao i usmjerenosti prema budućnosti. Iz tih propovijedi su, tijekom vremena, u nordijskim zemljama nastali simbotipovi (engl. symbotypes), repozitoriji kulturnih informacija koji opisuju viziju dobrog društva. Simbotipovi djeluju na oblikovanje sustava vrijednosti, uvjerenja, normi, nacionalnog identiteta i dominantnog načina djelovanja pojedine zemlje. Nalaze se u školskim knjigama, vizualnim

13 Zbog ograničenog prostora detaljna analiza poveznica nije izvediva.

14 Ovo pravilo vrijedi na svim razinama organizacije društva. Djelovanje u skladu s ovim aksiomom predstavlja jedan od ključnih čimbenika uspješnosti nordijiskih zemalja. 
umjetnostima i medijima. Iz početnih zajedničkih osnova tijekom vremena oblikovana su tri distinktivna nacionalna simbotipa. Witoszek i Sørensen (2018:37) norveški simbotip nazivaju zajednica dobrote (engl. Community of Goodness), danski sretno kršćanstvo (engl. Happy Christianity), a švedski dom naroda (engl. People’s Home).

Teolog, pjesnik i filozof Nicolai Frederik Severin Grundtvig (1783.-1872.) imao je presudan utjecaj na oblikovanju danskog simbiotipa. Grundtvig je propovijedao viziju „sretnog evangelističkog kršćanstva“ koju je nastojao ostvariti pomoću novog modela obrazovanja. Ključni element tog modela predstavljalo je stvaranje mreže narodnih gimnazija koje su, među ostalim, imale zadaću poticati razvoj zajedničkog sustava vrijednosti. Učenicima u gimnazijama nije se pristupalo kao pojedincima koji se međusobno natječu, već kao članovima zajednice koja u prvi plan ističe njegovanje sretnog života i dobrih odnosa s drugima. Grundtviški simbotip „sretnog kršćanstva“ tijekom vremena izgubio je svoju religijsku dimenziju, ali je oblikovao snažno i trajno humanističko nasljeđe u danskom i u norveškom Bildungu.

Prema Andersen i Björkmanu (2017:14) termin bildung označava pristup odgoju i obrazovanju koji potiče i omogućuje osobni razvoj pojedinaca i njihovo postupno preuzimanje sve veće odgovornosti prema obitelji, prijateljima, sugrađanima, društvu, čovječanstvu, planeti i globalnom nasljeđu naše vrste, pri čemu se vodi računa i o očuvanju njihove osobne slobode. Riječ je o procesu socijalizacije (postupnog usvajanja kulturalnih normi) i cjeloživotnog učenja koji pojedince potiče da se stalno razvijaju. Andersen i Björkman (2017:7) smatraju da je ovaj proces bio politički projekt tadašnjih političkih i kulturalnih elita koje su početkom 19. stoljeća prepoznale nastanak industrijske civilizacije, kao i potrebu psihološkog razvoja seljaka (kasnije i radnika) za odgovorno građanstvo.

Kumulativni učinci djelovanja nacionalnih simbotipova, posebno u kombinaciji s primjenom ključnih principa dizajna sustava, očituju se u nastanku prosocijalnog ponašanja. Prema Wilsonu (2019) termin „prosocijalno“ odnosi se na stav, uvjerenja ili ponašanja orijentirana na dobrobit drugih ili društva u cjelini. Naime, kao što Witoszek i Midttun (2018:7) navode ovaj snažni kooperativni i pragmatični etos, kada se prenese u ekonomsko i političko područje donosi ,alkemiju“ političke suradnje te relativno prosocijalni model kapitalizma. Sve navedeno potaknulo je Midttuna (2018:157) na zaključak da su nordijske zemlje sa svojim snažnim i kompetentnim državama i pragmatičnom prosocijalnom kulturom bolje pozicionirane od većine drugih zemalja da ostvare i transformativnu tranziciju prema eko-modernizmu na inkluzivan i pravedan način.

\subsection{Normativno-kulturalno područje}

U nordijskim se zemljama obrazovanje smatra ključnim mehanizmom razvoja pravednog i ravnopravnog društva koje podržava demokraciju, participaciju, dobrobit ljudi i cjeloživotno učenje. Ključni elementi nordijskog obrazovnog modela (Klette, 2018:59) su: (a) proces devetogodišnjeg osnovnog obrazovanja (K-9) koji svim učenicima, bez obzira na socijalno, ekonomsko i zemljopisno podrijetlo, pruža iste obrazovne moguć- 
nosti; (b) fokus na uključivanje i integrirana rješenja; (c) nacionalni kurikulum i (d) nastavne prakse koje naglašavaju suradnju i aktivnu ulogu učenika.

Zajednički nazivnik nordijskog sustava obaveznog školovanja datira još od Grundtviga i njegovih ideja o školovanju kao dijelu razvoja odgovornog građanstva, demokracije i „cjelovitog čovjeka“. Istraživanja nordijskih obrazovnih sustava ukazala su na to da se oni zasnivaju na vrijednostima jednakosti u smislu jednakog pristupa i mogućnosti, participacije i školovanja kao sredstva njegovanja demokratskih vrijednosti i socijalne mobilnosti te pedagogije usmjerene na učenika. Sukladno vrijednostima jednakosti, nordijske zemlje imaju sustav besplatnog školovanja na svim razinama obrazovnog sustava.

\subsection{Društveno-političko područje}

Društveno-političko područje višerazinski je sustav jedinica (na nacionalnoj, regionalnoj i lokalnoj razini) funkcioniranje kojih obilježava inherentno postojanje sukoba oko raspodjele političke i ekonomske moći. No, dizajn i način funkcioniranja društveno-političkog sustava presudno utječe na obilježja i intenzitet tih sukoba. Brandal i Thorsen (2018:161) smatraju kako uspjeh nordijskih zemalja proizlazi iz načina na koje su one uspjele prevladati sukobe između jedinica na različitim razinama organizacije društva, kao i jedinica unutar iste razine. Poluga za prevladavanje tih sukoba sastoji se od specifične kombinacije individualizma i komunitarizma koja osigurava uravnoteživanje potreba i sloboda pojedinaca s potrebama zajednice. Proces uravnoteživanja potreba pojedinaca i zajednice zasniva se na gore opisanim vrijednostima koje podržavaju i individualizam (prava i slobode pojedinca...) i komunitarizam (društvena jednakost, pravda, solidarnost...).

Nordijske zemlje imaju proporcionalne izborne sustave (Freinacht, 2017:78) što rezultira ulaskom u parlamente od 6 do 10 stranaka. Tako velik broj stranaka u parlamentu implicira nužnost koaliranja, kao i usvajanje promišljenog (engl. deliberative) pristupa kreiranju javnih politika. Dugogodišnji utjecaj simbotipova rezultirao je nastankom zajedničkog sustava vrijednosti te svjetonazorskog približavanja stranaka ljevice i desnice. Lakey (2016:62) opisuje iskustvo praćenja predizborne debate 1973. na norveškoj televiziji. Rasprava predstavnika političkih stranaka bila je gotovo dosadna - predstavnici svih stranaka zalagali su se za iste vrijednosti i predlagali slična rješenja. Pod dojmom iskustava praćenja predizbornih rasprava u $\mathrm{SAD}$-u, njegova prva reakcija bila je negativna. No, nakon razmišljanja zaključio je kako je to dokaz konsenzusa političkih stranaka o vrijednostima i ključnim pitanjima razvoja norveškog društva kao što su primjerice puna zaposlenost, nužnost regulacije tržišta, besplatna i univerzalna zdravstvena zaštita, besplatno visoko obrazovanje te učinkovit i pristupačan javni prijevoz.

Ključna obilježja nordijskog modela oblikovanja javnih politika, prema Brandal i Thorsen (2018:162), su:

a) uključivanje širokog kruga dionika. To nužno implicira promjenu obilježja (multilateralno pregovaranje) i dinamike procesa oblikovanja javnih politika. Premda ovaj pristup ima određene slabosti (u smislu brzine i troškova), njegove prednosti (npr. transparentnost procesa odlučivanja, kvaliteta i legitimitet odluka, te visoka razina 
povjerenja) to višestruko nadoknađuju;

b) postavka o tome kako politika, a ne slijepe sile povijesti ili tržišta, oblikuje svijet. Sukladno tome razvijen je sustav regulacije tržišta (npr. tržišta rada) i socijalnog sustava;

c) solidarnost kao temeljna postavka razvoja socijalnog sustava. To znači da su socijalni sustavi (npr. zdravstvo, obrazovanje, mirovinski) univerzalno strukturirani, tj. namijenjeni svima;

d) odgovornost države za osiguranje uvjeta za razvoj kritičke javnosti kao pretpostavke očuvanja demokracije. Jedan od mehanizama kojim se to ostvaruje jest organiziranje malih lokalnih zajednica s izravno izabranim političarima koji su u neposrednoj interakciji s biračima. Visoka razina političke pismenosti, kao i različiti oblici neposredne komunikacije izabranih lokalnih političara s ljudima predstavljaju ključne preduvjete ostvarenja ove ideje. Naredni mehanizam za očuvanje sfere kritičke javnosti predstavlja subvencioniranje novina na lokalnoj i nacionalnoj razini.

\subsection{Tehno-ekonomsko područje}

Klasični pristup dizajnu ekonomskih sustava (Lakey, 2016:73) polazi od (implicitne) postavke o nužnosti postojanja visoke stope nezaposlenosti i niske razine sigurnosti zaposlenja. Kumulativni učinak djelovanja ovako dizajniranih ekonomskih sustava očituje se u niskoj razini socijalne sigurnosti i visoke razine egzistencijalnog straha radno ovisnog stanovništva. Budući da nesigurnost i strah rađaju otpore promjenama, u tako dizajniran ekonomski sustav ugrađeno je ograničenje unapređenju njegove efikasnosti. Nasuprot tome, pristup dizajnu ekonomskog sustava nordijskih zemalja zasniva se na postavci o nužnosti razvoja sigurnosti za sve članove društva. U skladu s postavkom o sigurnosti za sve članove društva najvažniji je cilj ekonomskih politika u nordijskim zemljama puna zaposlenost.

Nordijski model tržišta rada zasniva se na bazičnoj socijalnoj sigurnosti. Nju omogućuju institucionalni aranžmani koji radnicima i njihovim obiteljima osiguravaju sredstva za život u turbulentnim tržišnim uvjetima (Midttun, 2018:139). Ključni mehanizmi regulacije tržišta rada su „fleksigurnost“ i centralizacija kolektivnih pregovora o politici plaća. Pojam fleksigurnost označava novi društveni ugovor između države, poslodavaca i radnika. Za razliku od tradicionalnog društvenog ugovora, koji je bio statičan jer je jamčio sigurnost zaposlenja, novi je ugovor dinamičan jer radnicima jamči socijalnu sigurnost neovisno o zaposlenju. Konkretno, prvi dio termina fleksigurnost odnosi se na tzv. numeričku fleksibilnost, tj. pravo poslodavaca da otpušta ekonomske viškove radnika. Drugi dio sintagme odnosi se na jamstvo države u pogledu pružanja trajne podrške otpuštenim radnicima u obliku naknada za nezaposlenost, osiguranja sredstava i materijalnih uvjeta za prekvalifikaciju te poduzimanja mjera aktivne politike zapošljavanja. Analiza učinaka politike fleksigurnosti (Lakey, 2016:21) pokazala je kako ona donosi koristi svim sudionicima. Vlasnicima omogućuje zatvaranje neefikasnih poduzeća, te realokaciju kapitala u atraktivnije projekte. Radnicima omogućuje zaštitu životnog standarda tijekom tranzicije s jednog na drugo zaposlenje, kao i pomoć pri razvoju novih sposobnosti kao preduvjet buduće 
zapošljivosti. Prednost za državu sastoji se u preusmjeravanju sredstava od subvencioniranja neefikasnih poduzeća u poticanje razvoja i osiguranje stalnog rasta konkurentnosti.

\subsection{Socijalno područje}

Švedski povjesničar Trägårdh (2018:79-94) smatra da „švedski model“ (kao varijanta nordijskog modela) predstavlja društveni ugovor između države i građana koji je postigao produktivnu i održivu ravnotežu između suradnje i kompromisa s jedne te autonomije pojedinca s druge strane. Prema tom društvenom ugovoru (koji predstavlja oblik materijalizacije švedskog simbotipa „narodnog doma“) ostvarivanje primarnih socijalnih prava (mirovine, naknade za nezaposlenost, porodiljni dopusti, bolovanje...) zasniva se na načelu reciprociteta, tj. na proporcionalnom odnosu između doprinosa i prava. Sekundardna socijalna prava (npr. zdravstvo, obrazovanje, zbrinjavanje mladih, starih i radno nesposobnih) zasnivaju se na načelu solidarnosti.

\section{PRELIMINARNE OCJENE STANJA U HRVATSKOJ ${ }^{15}$}

Kao i u prethodnom poglavlju, u nastavku slijedi ocjena ostvarene razine modernizacije hrvatskog društva, a zatim se navode podaci o poziciji Hrvatske na rang listama s pripadajućim izvorima (Tablica 1).

Proces tehno-ekonomske i socijalne modernizacije u Hrvatskoj odvijao se u razdoblju od 1950. do 1980. (Vuković, 2018). Tada je izgrađen ogroman dio gospodarske i socijalne infrastrukture koja se koristi i danas, a BDP per capita (u stalnim US dolarima) povećan je za 5,2 puta. Međutim, Hrvatska 80 -tih ulazi u razdoblje relativne stagnacije koje traje sve do danas.

Tablica 1. Pozicija Hrvatske na rang listama

\begin{tabular}{|c|l|}
\hline $\begin{array}{c}\text { Pozicija Hrvatske / ukupni } \\
\text { broj zemalja }\end{array}$ & \multicolumn{1}{|c|}{ Izvor } \\
\hline $22 . / 162$ & Sustainable Development Report 2019 (Sachs i sur., 2019:20) \\
\hline $75 . / 156$ & World Happiness Report (Helliwell i sur., 2019:25) \\
\hline $46 . / 189$ & Human Development Indicators and Indices (UNDP, 2018:32) \\
\hline $63 . / 141$ & The Global Competitiveness Report 2019 (Schwab, 2019:179) \\
\hline
\end{tabular}

Razlike u poziciji Hrvatske na analiziranim rang listama upućuju na oprez pri zaključivanju. Kroz izbor pokazatelja i njihovu interpretaciju prelamaju se razlike između službenog i neslužbenih narativa o stanju u Hrvatskoj. U odnosu na temu provedbe COR-ova preferirani je izvor službenog narativa Sustainable Development Report 2019 (SDR 2019) prema kojem se Hrvatska nalazi na 22. mjestu (Vlada RH, 2019:8). 
Zbog nekritičkog odnosa predstavnika državnih institucija prema nalazima SDR 2019, potrebno je ukazati na važnost sustavnog pristupa analizi i ocjeni postojećeg stanja. Premda pokazatelji korišteni u izradi SDR 2019 ukazuju na relativno zadovoljavajuće stanje zdravstvenog sustava, neki drugi pokazatelji (npr. o dugovima zdravstvenog sustava, o odljevu medicinskog kadra i listama čekanja) ukazuju na brojne slabosti. Kako je riječ o sustavu koji je dinamički, društveno i generativno kompleksan, ocjena stanja i prijedlozi rješenja trebali bi se zasnivati na novom pristupu. Riječ je o pristupu kojim bi se, među ostalim, trebalo osigurati uključivanje svih relevantnih dionika (liječnika, medicinskog osoblja, pacijenata, ravnatelja, privatnih poliklinika...) pri analizi i ocjenjivanju stanja, kao i korištenje sustavnog načina mišljenja. Hrvatsko zdravstvo može se prikazati kao sustav od tri komponente (vidi Sliku 3) ${ }^{16}$ :

a) inputi: financijska sredstva, ljudi,materijalna sredstva (zgrade i oprema), liderstvo (lideri imaju ključnu ulogu u dizajnu i vođenju sustava);

b) stanje sustava: npr. zaposleni (broj, kvalifikacijska i starosna struktura); oprema, objekti, zalihe potrošnih materijala, financijska sredstva, organizacijska klima i kultura u zdravstvenim institucijama...;

c) outputi: pokazatelji rezultata zdravstvenog sustava.

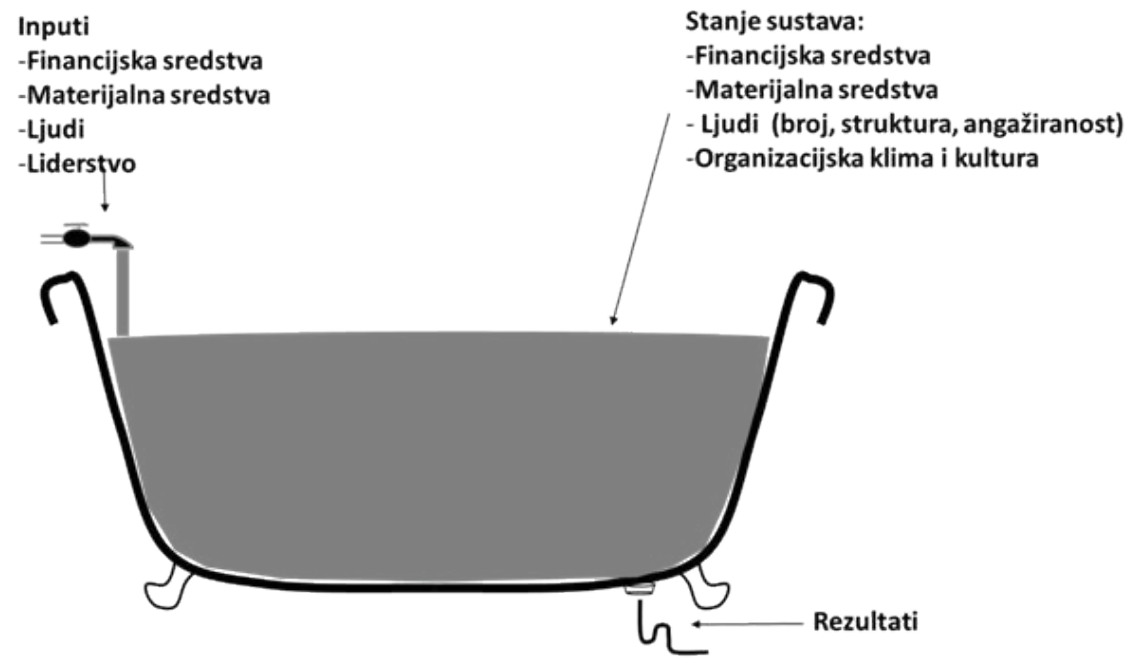

Slika 3. Mapa zdravstvenog sustava

Metodologija za praćenje provedbe COR-ova uglavnom je usmjerena na rezultate. No, rezultati hrvatskog zdravstva presudno ovise o inputima i stanju sustava. Javno dostupni podaci o ulaganjima i zapošljavanju s jedne, kao i o postojećem i očekivanom odljevu medicinskog kadra (zbog odlaska u inozemstvo ili u mirovinu) s druge strane ukazu-

16 Riječ je o metafori „kade“, mentalnom modelu korisnom za razumijevanje funkcioniranja kompleksnih društvenih i prirodnih sustava (Sweeney, 2016) 
ju na rizik značajnog smanjenja kapaciteta sustava za izvršavanje temeljnih funkcija u budućnosti. Posljedično tome, u fokusu praćenja i izvještavanja (kao temelj za vođenje javnih politika) trebaju biti ne samo rezultati, nego inputi i stanje zdravstvenog sustava. Ovaj metodološki pristup može se primijeniti na analize i nekih drugih društvenih (npr. mirovinski, socijalni, obrazovni) i / ili prirodnih sustava (npr. klima).

\subsection{Dominantne vrijednosti}

$\mathrm{Na}$ temelju dostupnih informacija smatramo kako hrvatski simbotip, u smislu eksplicitne vizije dobrog društva, ne postoji. Stoga se u nastavku navode teze o dominantnim vrijednostima hrvatskog društva. Dominantna vrijednost na individualnoj razini individualni je utilitarizam - stjecanje materijalnih i drugih društvenih dobara i usmjerenost na koristoljublje, dok na socijetalnoj razini postoje barem tri dominantne vrijednosti: radikalni egalitarizam, solidarnost i autoritarnost (Županov, 2011:156). Egalitarni sindrom Županov (1977:30) konceptualizira kao klaster koji čini sedam komponenti: perspektiva ograničenog dobra, redistributivna etika, egalitarna raspodjela, opsesija o privatniku, antiprofesionalizam, intelektualna uravnilovka i antiintelektualizam ${ }^{17}$. Potaknuti kritikom Dolenec (2014), Štulhofer i Burić (2015) te Burić i Štulhofer (2016) testirali su empirijsku utemeljenost teorije egalitarnog sindroma. Rezultati njihovih istraživanja govore u prilog prihvaćanja Županovljevih teza. Utvrđena prihvaćenost vrijednosti koje čine egalitarni sindrom, a osobito perspektiva ograničenog dobra, antipoduzetnički sentiment i sklonost državnom paternalizmu omogućuju bolje razumijevanje nastanka različitih oblika društveno disfunkcionalnih, antisocijalnih ponašanja kao što su neracionalnost teritorijalnog ustroja, korupcija i „uhljebljivanje“ stranačkih kolega i drugih pojedinaca, politički klijentelizam, hipertrofija državnih institucija i agencija, velika ovisnost nekih socijalnih skupina o državnim transferima, velika državna potrošnja itd.

Dodatni uvid u strukturu sustava vrijednosti hrvatskog društva proizlazi iz rezultata istraživanja World Value Surveya (2019) (vidi Sliku 4) koje polazi od dviju ključnih dimenzija:

a) vrijednosti preživljavanja u odnosu na vrijednosti samoostvarenja;

b) tradicionalne vrijednosti u odnosu na sekularno-racionalne.

Vrijednosti preživljavanja naglašavaju ekonomsku i fizičku sigurnost. Proizlaze iz entnocentričnih pogleda na svijet, odlikuju se niskom razinom povjerenja i tolerancije (pr. prema strancima, rodnoj jednakosti ili osobama drugačije političke orijentacije). Vrijednosti samoostvarenja pridaju veliku važnost subjektivnoj dobrobiti i kvaliteti života. U društvima koja prihvaćaju vrijednosti samoostvarenja posebna pažnja pridaje se zaštiti okoliša, toleranciji prema strancima, rodnoj jednakosti, zahtjevima za sudjelovanjem u odlučivanju o političkim i ekonomskim pitanjima, povjerenju, političkoj umjerenosti, te promjeni u odgoju djece od naglaska na naporni rad prema kreativnosti i toleranciji.

17 Zbog ograničenog prostora opis i analiza pojedinih komponenti klastera egalitarnog sindroma nije moguća. 
Tradicionalne vrijednosti naglašavaju važnost religije, poštovanje autoriteta i tradicionalnih obiteljskih vrijednosti. Ljudi koji prihvaćaju te vrijednosti ne prihvaćaju razvod braka, abortus, eutanaziju i samoubojstvo. Društva koja prihvaćaju te vrijednosti imaju visoku razinu nacionalnog ponosa i nacionalistička stajališta. Sekularno-racionalne vrijednosti imaju suprotne preferencije u odnosu na tradicionalne vrijednosti. Društva koja prihvaćaju te vrijednosti manje naglašavaju religiju, tradicionalne obiteljske vrijednosti i autoritet.

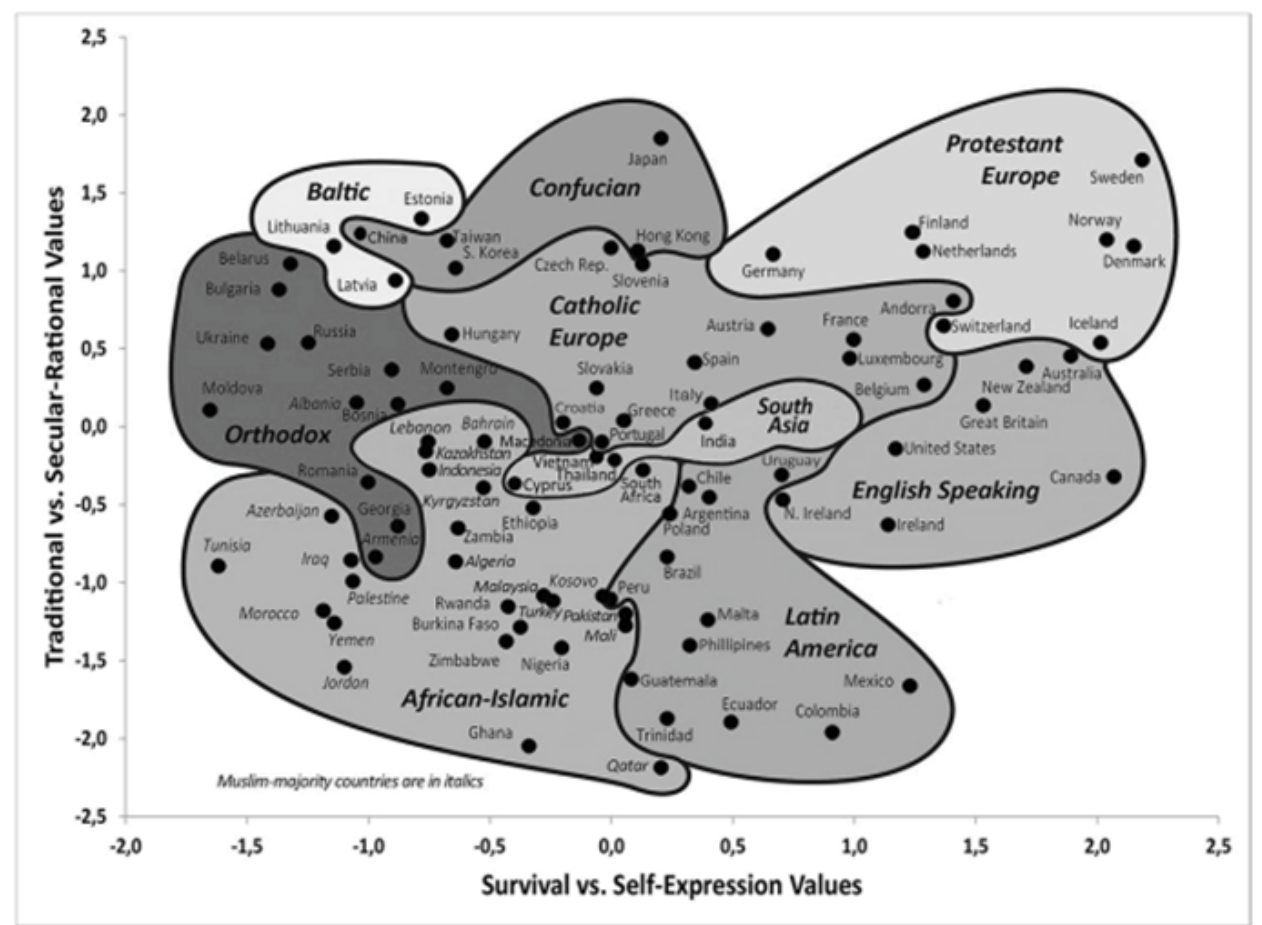

Slika 4. Kulturna karta svijeta (WVS, 2019)

Pozicija Hrvatske na gornjoj slici ukazuje na njeno zaostajanje u odnosu na nordijske zemlje. No, još važniji zaključak proizlazi iz uvida u trend promjena. U razdoblju između 1996.-2019. Hrvatska je „otklizala“ ispod nule na horizontalnoj koordinati prema vrijednostima preživljavanja te pala na vertikalnoj koordinati prema tradicionalnim vrijednostima. Ovi regresijski trendovi posljedica su djelovanja brojnih čimbenika: ratnih događanja, grešaka u razvojnoj i ekonomskoj politici (koje su dovele do gubitka stotina tisuća radnih mjesta), kao i negativnih procesa u odgojno-obrazovnom sustavu. Naime, prema GOOD Inicijativi (2015) Hrvatska je jedna od rijetkih zemalja koja ne provodi sustavni građanski odgoj i obrazovanje te nema razvojnu viziju i jasno definiran plan kako ovaj sadržaj kvalitetno integrirati u postojeći ili izmijenjeni obrazovni sustav. U skladu s modelom prikazanim na Slici 2 u nastavku slijedi analiza četiriju područja. 


\subsection{Normativno-kulturno područje}

Obrazovni sustav u Hrvatskoj nema status ključnog mehanizma za ostvarivanje društvenog razvoja. U izjavama najviših državnih dužnosnika ukazuje se samo na važnost obrazovanja kao pripremu za ulazak na tržište rada. S tim u vezi, Jokić i Ristić-Dedić (2019) navode da zbog toga što hrvatsku politiku nije zanimala modernizacija društva, odgojno obrazovni sustav nije pratio svjetske razvojne trendove. Umjesto toga, izložen je ideološkoj indoktrinaciji (Koren, prema Dauenhauer, 2019). Netom navedeno predstavlja osnovu za tezu o tome kako postojeći sustav obrazovanja i odgoja ne priprema učenike za formuliranje odgovora primjerenih izazovima 21. stoljeća.

U prilog toj tezi govore rezultati globalnog istraživanja o konkurentnosti, istraživanja PISA i državne mature. Istraživanje o konkurentnosti (Schwab, 2019:181) ukazalo je na slabosti u kritičkom mišljenju, nisku razinu umijeća nakon srednjeg obrazovanja, kao i nisku razinu digitalnih kompetencija. Istraživanja PISA, provedena 2015. (Ma. B., 2016), pokazala su da hrvatski srednjoškolci u sva tri područja (prirodoslovna, matematička i čitalačka pismenost) značajno zaostaju za prosjekom zemalja OECD-a. Prema analizama Nacionalnog centra za vanjsko vrednovanje, rezultati na državnoj maturi su od 2015. sve lošiji (Ivandić, 2019).

Korištenje ovih nalaza kao podloge za kritiku nastavnog osoblja ukazuje na nerazvijenost sposobnosti sustavnog načina razmišljanja. Naime, obrazovanje je vrlo kompleksan sustav. To znači da su uzroci (npr. kvaliteta rada nastavnog osoblja) i posljedice (rezultati obrazovnog sustava) međusobno odvojeni u prostoru i vremenu (ponekad je riječ o razdoblju od više desetljeća - vidi Pavičić, 2019). Simplicistički pristupi, kao rezultat analitičkog načina razmišljanja, koji odgovornost za rezultate vezuju primarno za nastavno osoblje ukazuju na nerazumijevanje obilježja kompleksnih socijalnih sustava. $S$ tim u vezi potrebno je podsjetiti kako je Deming (2000) još prije mnogo godina konstatirao da se $94 \%$ uzroka problema nalazi u sferi sustava (pri čemu je potrebno podsjetiti kako dizajn sustava spada u područje odgovornosti političkih lidera i menadžmenta u obrazovnom sustavu), a samo 6\% otpada na „posebne“ čimbenike (npr. nastavno osoblju). Riječju, odgovornost za loše rezultate obrazovnog sustava, u nas, u prvom redu snose "dizajneri sustava“, a ne nastavno osoblje.

\subsection{Društveno-političko područje}

Iz procesne perspektive društveno-političko područje moguće je raščlaniti na tri segmenta. Prvi od njih odnosi se na izborni sustav (koji obuvaća državnu, županijsku i lokalnu razinu), drugi na sustav oblikovanja javnih politika (koji obuhvaća izvršnu i zakondavnu vlast na državnoj, županijskoj i lokalnoj razini), treći na sustav provedbe javnih politika (koji obuhvaća javnu upravu i pravosuđe na državnoj, županijskoj i lokalnoj razini, kao i niz državnih agencija). Pored političkih stranaka (koje imaju ključnu ulogu), u političkim procesima sudjeluju građani (u ulozi birača), mediji te organizacije koje predstavljaju interese različitih socijalnih skupina: poslodavci, sindikati, udruge građana (pr. za zaštitu okoliša ili veteranske udruge) i sl. 
Prema nedavno objavljenim rezultatima istraživanja (Čepo, 2020) jedan od ključnih trendova na društveno-političkom području odnosi se na činjenicu da dominantne političke stranke zarobljavanje ili marginaliziraju neke od ključnih komponenti sustava liberalne demokracije ${ }^{18}$ - što rezultira „demokratskim nazadovanjem“ Hrvatske.

Hrvatska ima proporcionalni izborni sustav pa tako aktualni saziv Hrvatskog sabora čine predstavnici 12 političkih stranaka. Tako velik broj političkih stranaka zahtijeva koaliranje, a dosadašnja iskustva o funkcioniranju koalicijskih vlada ukazuju na njihovu nestabilnost. Prema istraživanju o socijalnom dijalogu (Cimeša i Marinković Drača, 2002) nestabilnost političkih koalicija posljedica je izostanka zajedničke vizije i strategije razvoja, kao i nedostataka u koalicijskom ugovoru.

Rezultati istraživanja o učinkovitosti javne uprave (Blavatnik School of Government i Institute for Government, 2019:36) pokazuju kako se Hrvatska nalazi na 35. mjestu od ukupno 38 država. Najbolje je ocijenjeno stanje u području upravljanja porezima, dok su područja digitalnih usluga, kreiranja javnih politika te otvorenosti (tj. stupnja savjetovanja predstavnika institucija $s$ građanima u procesu kreiranja javnih politika) najlošije ocijenjena. Riječju, ovo istraživanje predstavlja još jednu potvrdu teze o neučinkovitosti javne uprave u Hrvatskoj. Ogroman problem predstavlja i teritorijalni ustroj zemlje koji paralizira modernizaciju tijela javne vlasti na svim razinama.

\subsection{Tehno-ekonomsko područje}

Tehno-ekonomsko područje obilježavaju trendovi nepovoljnih promjena u ekonomskoj strukturi (Tablica 2).

Tablica 2. Struktura gospodarstva Hrvatske 1989.-2017. u \% (Domazet, 2018)

\begin{tabular}{|l|c|c|}
\hline & 1989. & 2017. \\
\hline Poljoprivreda, šumarstvo, ribarstvo & 12,1 & 3,0 \\
\hline Prerađivačka industrija & 37,8 & 15,5 \\
\hline Građevinarstvo & 5,3 & 4,2 \\
\hline Trgovina, prijevoz, smještaj, hrana & 14,1 & 20,5 \\
\hline Informacije i komunikacije & 1,5 & 3,8 \\
\hline Financije i osiguranje & 0,8 & 5,5 \\
\hline Poslovanje nekretninama & 3,6 & 8,5 \\
\hline Stručne, znanstvene djelatnosti & 5,7 & 7,0 \\
\hline Javna uprava, obrana, obrazovanje, zdravstvena zaštita, socijalna skrb & 9,8 & 12,0 \\
\hline
\end{tabular}

18 Npr. mediji, uprava, pravosuđe, institucije zadužene za zaštitu demokratskih standarda, institucije lokalne samouprave i sl. 
Iz gornje tablice vidljiv je značajan pad udjela poljoprivrede (što je rezultiralo produbljivanjem strateškog problema prerhrambene samodostatnosti) i prerađivačke industrije (što predstavlja dokaz teze o trendu „deindustrijalizacije“). Uzroke ovih negativnih trendova treba tražiti u nepostojanju koncepcije, vizije i strategije razvoja Hrvatske te u mjerama ekonomske politike (npr. privatizacija, tečaj). Primjerice, prema Izvješću o radu na provedbi revizije pretvorbe i privatizacije (Državni ured za reviziju RH, 2001) procesom revizije bilo je obuhvaćeno 1.556 poduzeća. Revizija je pokazala sljedeće:

- smanjenje temeljnog kapitala za $16 \%$

- smanjenje broja zaposlenih za $60 \%$

- ciljevi razvojnog programa nisu ostvareni (djelomično ili u cjelini) u 85\% poduzeća.

\subsection{Socijalno područje}

Ključni su pokazatelji stanja na socijalnom području stopa zaposlenosti stanovištva i ekonomske nejednakosti. Prosječna stopa zaposlenosti u EU iznosi 73,1\%, a u Hrvatskoj 66\% (Eurostat, 2019). Relativno niska stopa zaposlenosti ukazuje na niski potencijal izdvajanja za socijalne transfere (što je još očitije kad se analizira odnos zaposlenih i umirovljenika).

GINI indeks dohodovne nejednakosti za Hrvatsku iznosio je 30,0 (DZS, 2017). No, potpunija slika o ukupnim nejednakostima u Hrvatskoj proizlazi iz analize Hrvatske narodne banke prema kojoj je indeks nejednakosti štednje na ekstremnoj razini od 0,8 (Ivanković, 2016). Analiza HNB pokazala je da $1 \%$ najbogatijih drži oko $25 \%$ štednje, dok 30\% najbogatijih drži 98\% ukupne štednje (prema Ivanković, 2016).

\section{DISKUSIJA}

Prezentacija rezultata preliminarnih ocjena stanja ukazala je na nezadovoljavajuću situaciju u sva četiri područja. Neke posljedice takvog stanja već su vidljive (npr. konkurentsko zaostajanje, ekonomske nejednakosti, trend iseljavanja, pad na rang ljestvicama EU), a neke bi se mogle dogoditi (npr. kolaps zdravstvenog i mirovinskog sustava) ne provedu li se u međuvremenu transformativne promjene.

Navedeni nalazi predstavljaju simptome problema. Jedan je od najvažnijih simptoma problema hrvatskog društva nejednakost. Stoga se u skladu sa Slikom 1, u nastavku ukazuje na strukturu sustava koji genereira nejednakosti. Prvi indikator za prepoznavanje strukture sustava predstavljaju obrasci ponašanja, odnosno trendovi promjena ključnih varijabli. U konkretnom slučaju riječ je o trendovima rasta političke i ekonomske moći pripadnika socijalne skupine „A“, kao i o trendovima pada političke ekonomske moći pripadnika socijalne skupine „B“ (vidi Sliku 5).

Iz Slike 5 proizlazi kako skupina A tijekom vremena dobiva sve više resursa i stječe sve veću ekonomsku i političku moć. Nasuprot tome, pripadnici skupine B tijekom vremena dobivaju sve manje resursa te imaju sve manju ekonomsku i političku moć. 


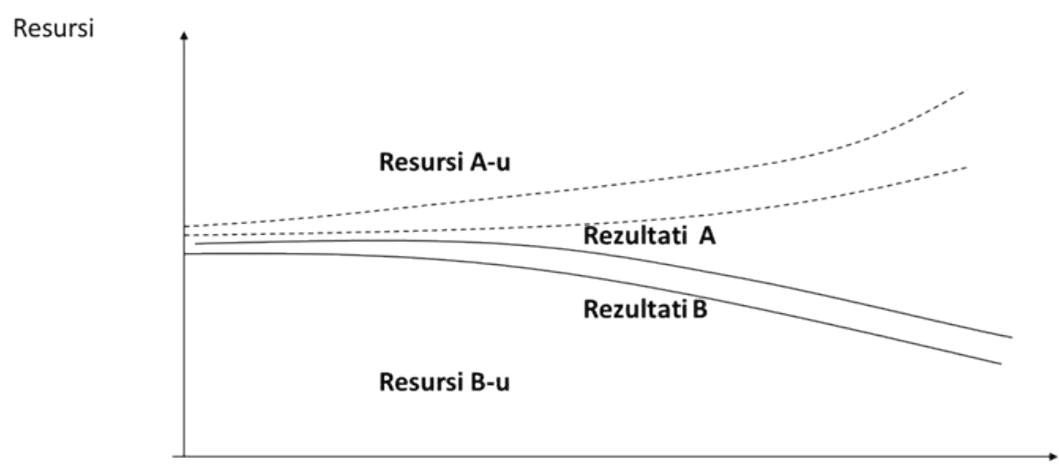

\section{Slika 5. Obrasci ponašanja: rast nejednakosti}

Ukratko, u pitanju je dinamika rasta nejednakosti između skupine A i skupine B. Prema Sengeu (2001:363) ovakvi obrasci ponašanja ukazuju na to da je riječ je o sustavnom arhetipu $^{19}$ "uspjeh uspješnima“ (engl. sucess to sucesfull). Empirijske podloge za korištenje ovog arhetipa proizašle su iz istraživanja „Naša zarobljena mista“ (Hofman i sur., $2017)^{20}$. Ključna je poruka ovog istraživanja da stjecanje sve veće ekonomske i političke moći pripadnika skupine A tijekom vremena rezultira „zarobljavanjem“ javnih institucija i resursa pojedinih političara i njihove „klijentele“. Presudnu ulogu u tom procesu imaju nositelji izvršne vlasti na lokalnoj razini ${ }^{21}$ - načelnici i gradonačelnici.

Prema Zakonu o lokalnim izborima (NN 144/12, 121/16, 98/19, 42/20) (grado)načelnici mogu biti i zastupnici u Saboru. To im daje mogućnost izravnog sudjelovanja u oblikovanje normativnog okvira u skladu sa svojim interesima - što rezultira rastom njihove moći (vidi krug R1 na Slici 6). Istraživanje Hofmana i suradnika (2017) ukazalo je na postojanje nekoliko tipova javnih politika, odnosno mehanizama alokacije javnih resursa (npr. zapošljavanje / kadroviranje, komunalno-građevinski zahvati, prostorno planiranje, mjere socijalne politike $)^{22}$, kao i na nekoliko ciljeva koji se njima ostvaruju (npr. širenje mreža, kontrola nad mrežama, povećanje količine i vrijednosti resursa, distribucija resursa, povećanje vjerojatnosti reizbora, osiguranje potpore drugih političkih opcija). (Grado)načelnici biraju ciljeve u skladu sa svojim interesima - što rezultira dodatnim rastom njihove moći (R2 na Slici 6).

19 Riječ je o oruđima sustavnog mišljenja koja se mogu koristiti dijagnostički (tj.za prepoznavanje obrazaca ponašanja i strukture sistema iz kojih oni proizlaze) ili prospektivno (tj. za oblikovanje sistemskih intervencija).

20 Istraživanje D. Čepa (2020) nudi dodatne uvide u ovu dinamiku.

21 U završnom dijelu studije Hofman i suradnici (2017:118) navode kako se ista praksa „pojavljuje u čitavoj državi“.

22 Jedan od ključnih mehanizama alokacije javnih resursa u početnoj fazi bila je pretvorba i privatizacija poduzeća. 


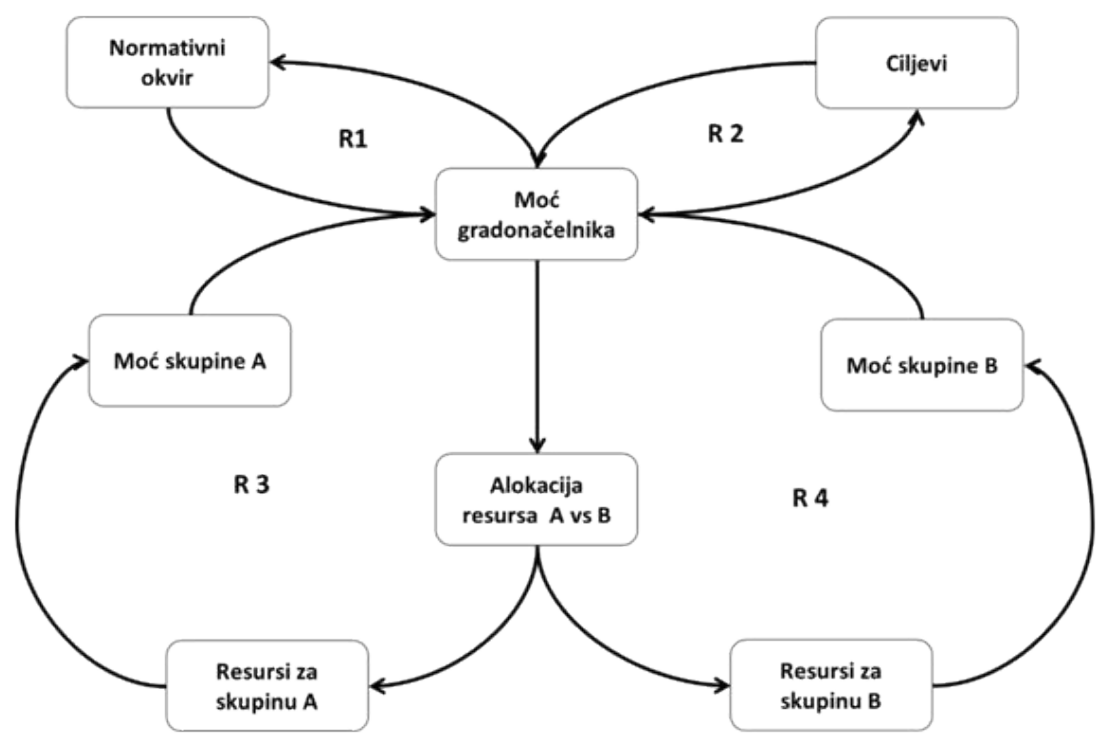

Slika 6. Uspjeh uspješnima

Odluke o alokaciji resursa - zapošljavanje, dodjeljivanje poslova na javnim natječajima, prostorno planiranje, raspodjela socijalnih prava i sl., (grado)načelnici donose neposredno ili posredno (tj. putem utjecaja na proces odlučivanja u skupštinama). Kriterij za alokaciju javnih resursa je interes (grado)načelnika i pripadnost političkoj opciji. U skladu s postavljenim ciljevima, autori navedenog istraživanja bavili su se mehanizmima alokacije resursa u korist skupine A. Tijekom vremena, alokacija resursa u korist skupine A, rezultira povećanjem njihove ekonomske i političke moći. Prema nepisanom dogovoru članovi skupine A glasaju za (grado)načelnika te mu osiguravaju reizbor (R3 na Slici 6). No, iz Slike 6 vidljivo je postojanje i druge stranu medalje: stvaranje širokog sloja „tranzicijskih gubitnika“ - skupine B čiji pripadnici imaju na raspolaganje (relativno) sve manje resursa i koji sve manje sudjeluju u političkim procesima ${ }^{23}$ (R4). Pošto ova dimenzija strukture sustava nije bila obuhvaćena navedenim istraživanjem, njeno dublje izučavanje trebalo bi predstavljati predmet nekih budućih projekata.

Potrebno je istaknuti kako krug R3 predstavlja prikaz sistemske strukture klijentelističkih i koruptivnih procesa ${ }^{24}$ koji rezultiraju nastankom "tranzicijskih pobjednik“, te „zarobljavanjem“ lokalnih zajednica. Rast ekonomske i političke moći „pobjednika“ dovodi do ekonomskih nejednakosti što prema Wilkinsonu i Picket (2018) izaziva brojne posljedice po...

23 U zaključku studije Hofman i suradnici (2017:117) navode kako ovakva socijalna dinamika kod pripadnika skupine „tranzicijskih gubitnika“ generiraju „osjećaj nemogućnosti i besmislenosti javnog djelovanja, pa sve do političke apatije i nezainteresiranosti“.

24 Razrađeni prikaz sustava korupcije u SAD-u donose Kotler i Sakar (2019), zajedno s prijedlogom rješenja. 
- fizičko zdravlje (očekivano trajanje života, mortalitet djece, mortalitet odraslih, pretilost, HIV infekcija)

- mentalno zdravlje i dobrobit (mentalne bolesti, depresija, šizofrenija, psihotični simptomi...)

- društvenu koheziju (povjerenje, solidarnost, građanska participacija, kulturna participacija, status žena...)

- životne šanse djece (dobrobit djece, nasilje, socijalna mobilnost..)

- ekološke probleme (bioraznolikost, emisija $\mathrm{CO}_{2}$, potrošnja vode / nafte / mesa...).

Premda su sve navedene posljedice značajne, potrebno je posebno istaknuti problem društvene kohezije (koji se očituje u padu povjerenja u institucije, kao i padu općeg povjerenja među ljudima), rastuće polarizacije u društvu, pada opće spremnosti na suradnju i međusobno pomaganje. Pored navedenog, porast nejednakosti u hrvatskom društvu, predstavlja i jedan od uzroka procesa iseljavanja iz Hrvatske.

Prema Slici 1, struktura sustava proizlazi iz dominantnih mentalnih modela, odnosno prevladavajućeg načina razmišljanja i sustava vrijednosti. $U$ točki 4.1. navedena su obilježja dominantnog načina razmišljanja i sustava vrijednosti (perspektiva ograničenog dobra, autoritarnost, egalitarni sindrom) koja su omogućila nastanak sustavnog arhetipa „uspjeh uspješnima“. Primjerice, perspektiva ograničenog dobra (engl. scarcity mentality) zasniva se na uvjerenju kako su raspoložive količine nekog dobra uvijek ograničene, nikad dovoljne za sve. Posljedično tome, „krug solidarnosti“ osoba koje tako razmišljaju obično je uzak: obuhvaća samo članove obitelji, lokalne sredine i neke druge oblike interesnog udruženja. Takve osobe nisu spremne dijeliti moć te materijalne i nematerijalne resurse. Dodatni čimbenik nastanka opisane strukturne dinamike predstavlja autoritarnost. Autoritarnost je osobina ličnosti, kao i društveni odnos koji obilježava zahtjev za poštivanjem autoriteta pojedinca ili institucija. Vrijednosni sustav zasnovan na autoritarnosti može rezultirati nastankom aristokratske paradigme (Sanford, 2017:74) koja se zasniva na postavci kako je mali dio populacije superiorniji u odnosu na ostale i stoga joj treba povjeriti donošenje odluka u ime svih. Ova ideja odražava tradicionalni način mišljenja, a manifestira se u uspostavljanju hijerarhijske organizacije i centralizaciji odlučivanja.

Za razliku od „nordijskog modela“ koji potiče prosocijalno ponašanje, hrvatski sustav generira asocijalno ponašanje u svim analiziranim područjima. U političkom području to je vidljivo u nespremnosti političkih stranaka za suradnju na ostvarivanju općih društvenih ciljeva, kao i izostanku stvarnog socijalnog dijaloga između predstavnika državnih institucija, poslodavaca i sindikata. U ekonomskom području asocijalno ponašanje vidljivo je u izabranom modelu privatizacije, izostanku suradnje poduzeća na razvoju klastera, rastućim nejednakostima, izostanku suradnje poslodavaca i radnika u poduzećima, kao i u odnosu državnih institucija prema NVO-u i neovisnim medijima. $\mathrm{Na}$ socijalnom području asocijalno ponašanje manifestira se kroz asimetričnu distribuciju socijalnih prava i privatizaciji dijelova obrazovnog, zdravstvenog, socijalnog i mirovinskog sustava. 


\section{ZAKLJUČCI I PREPORUKE}

Istraživanje je potvrdilo polaznu tezu o tome kako Hrvatska nije spremna na provedbu COR-ova. Da podsjetimo, u najnovijem izvješću o održivom razvoju navodi se kako u ovom trenutku nijedna zemlja nije na putu ostvarenja svih 17 ciljeva. U izvješću se također ukazuje na to kako su nordijske zemlje najdalje odmakle na tom putu. Analiza „nordijskog modela“ društvenog razvoja pokazala je kako se on zasniva na postojanju zajedničke vizije dobrog društva i kulturi suradnje koja se na tim prostorima razvijala od 16 stoljeća. Uvidi u funkcioniranje ključnih društvenih sustava pokazala je kako se kultura suradnje njeguje u obrazovnom sustavu te značajno utječe na funkcioniranje društveno-političkog, tehno-ekonomskog i socijalnog sustava.

Preliminarne ocjene stanja u Hrvatskoj ukazale se na nepostojanje opće prihvaćene zajedničke vizije dobrog društva, kao i odsustvo prosocijalnog ponašanja na svim područjima i na svim razinama društva. U takvim okolnostima provedba COR-ova u Hrvatskoj, u zadanim vremenskim okvirima, doista zahtijeva pokretanje transformativnih promjena. To je najvažnija moralna obveza sadašnjih lidera prema budućim generacijama.

U skladu s ciljem rada navode se sljedeće preporuke:

- Razviti sustavni pristup izučavanju i transferu znanja o „nordijskom modelu“.

- Inicirati rad na razvoju kulture suradnje u državnim institucijama, poduzećima i nevladinim organizacijama. Pokretanje procesa razvoja „krugova suradnje“ omogućilo bi uspon nove generacije lidera spremnih i sposobnih da odgovore na izazove koje donosi budućnost.

- Inicirati proces razvoja hrvatskog transformacijskog sustava.

Nositelji ovih incijativa mogli bi biti Zajednica za društveno odgovorno poslovanje $\mathrm{Hr}$ vatske gospodarske komore, Hrvatski poslovni savjet za održivi razvoj (HRPSOR) i Global Compact Hrvatska - u suradnji s nadležnim državnim institucijama. Odluka o tome u rukama je lidera tih institucija. 


\section{LITERATURA}

Andersen L. R. i Björkman T. (2017). The Nordic Secret: A European Story of Beauty and Freedom. Stockholm: Fri Tanke förlag.

Atkins, P. W. B., Wilson, D. S. i Hayes, S. C. (2019). Prosocial: Using Evolutionary Science to Build Productive, Equitable and Collaborative Groups. Oakland, CA: New Harbinger Publication

Brandal, N. i Thorsen D. E. (2018). Between individualism and communitarianism: The Nordic way of doing politics. U: Witoszek, N. i Midttun A. (ur.), Sustainable Modernity: The Nordic Model and Beyond (str. 160-186). London i New York: Routlege.

Blavatnik School of Government i Institute for Government (2019). The International Civil Service Effectiveness (InCiSE) Indeks: Results Report 2019. Oxford: Blavatnik School of Government. URL: https://www.bsg.ox.ac.uk/sites/default/files/2019-04/ InCiSE\%202019\%20Results\%20Report.pdf (10.05.2020.)

Burić, I. i Štulhofer, A. (2016). In search of the egalitarian syndrome: cultural inertia in Croatia?. Financial Theory and Practice, 40(4): 361-382.

Cimeša, M. i Marinković Drača, D. (2002). Socijalni dijalog u Hrvatskoj. Zagreb: SSSH. Čepo, D. (2020). Structural weaknesses and the role of the dominant political party: democratic backsliding in Croatia since EU accession. Southeast European and Black Sea Studies, 20(1): 141-159.

Dauenhauer, N. J. (2019). Učenike se masovno indoktrinira nacijom i vjerom ne samo na vjeronauku. Zašto? Indeks.hr, 19. listopada 2019. URL: https://www.index.hr/ vijesti/clanak/ucenike-se-masovno-indoktrinira-nacijom-i-vjerom-ne-samo-na-vjeronauku-zasto/2125284.aspx (10.05.2020.)

Deming, W. E. (2000). Out of Crisis. Cambridge, MA: MIT Press.

Dolenec, D. (2014). Preispitivanje „egalitarnog sindroma“ Josipa Županova. Politička misao, 51(4): 41-64.

Domazet, T. (2018). Razina BDP-a 2017. godine je 4,1\% niža u odnosu na godinu prije krize (2008.), što znači da je Hrvatska još uvijek u krizi. Hrvatska danas, 5. ožujka 2018. URL: https://hrvatska-danas.com/2018/03/05/analiza-razina-bdp-a2017-godine-je-41-niza-u-odnosu-na-godinu-prije-krize-2008-sto-znaci-da-je-hrvatska-jos-uvijek-u-krizi/ (10.05.2020.)

Državni ured za reviziju RH (2001). Izvješće o radu na provedbi revizije pretvorbe i privatizacije. URL: http://www.revizija.hr/izvjesca/2007/revizije-pretvorbe-i-privatizacije/000-izvjesce_o_radu.pdf (10.05.2020.)

Državni zavod za statistiku (DZS) (2017). Pokazatelji siromaštva i socijalne isključenosti u 2016 - konačni rezultati. Priopćenje, 54 (14.1.1.). URL: https://www.dzs.hr/ Hrv_Eng/publication/2017/14-01-01_01_2017.htm (10.05.2020.)

Eurostat (2019). Statistika zaposlenosti. URL: https://ec.europa.eu/eurostat/statistics-explained/index.php?title=Employment_statistics/hr (10.05.2020.)

Freinacht, H. (2017). The Listening Society: A Guide to Metamodern Politics. Jægerspris: Metamoderna ApS. 
Global Footprint Network (GFN) (2020). Open Data Platform. URL: http:// data.footprintnetwork.org/?_ga=2.213333008.541499485.1589792108169197962.1589316632\#/ (10.05.2020.)

GOOD Inicijativa (2015). Polazišne osnove uvođenja građanskog odgoja i obrazovanja u škole. URL: http://goo.hr/wp-content/uploads/2015/11/2015_Polazisne-osnove_GOOD_Inicijativa.pdf (10.05.2020.)

Helliwell, J., Layard, R., i Sachs, J. (2019). World Happiness Report 2019. New York: Sustainable Development Solutions Network.

Hofman, D., Miošić-Lisnjak, N., Prkut, D., Stubbs, P., Šalaj, B., Zelić, D. i Zrinšćak,S. (2017). Naša zarobljena mista: Istraživački izvještaj studija kvalitete lokalnog javnog uprvaljanja u Hrvatskoj. Zagreb: GONG.

Intergovernmental Panel on Climate Change (IPCC) (2018). Global Warming of 1.5 ${ }^{\circ} \mathrm{C}$. Summary for Policymakers. URL: https:/www.ipcc.ch/site/assets/uploads/sites/2/2019/05/SR15_SPM_version_report_LR.pdf (10.05.2020.)

Ivandić, I. (2019). Objavljeni i službeni rezultati državne mature: Stvarno je gore nego ikad, praznih listova bilo je čak 1200! Tportal.hr, 15. srpnja 2019. URL: https:// www.tportal.hr/vijesti/clanak/objavljeni-i-sluzbeni-rezultati-mature-stvarno-je-gore-nego-ikad-20190715 (10.05.2020.)

Ivanković, Ž. (2016). Nejednakost: ključno društveno pitanje: Jedan posto Hrvata, njih 7.427, prosječno na svojem računu drži 4,5 milijuna kuna. Jutarnji list, 17 . veljače 2016. URL: https:/www.jutarnji.hr/vijesti/hrvatska/nejednakost-kljucno-drustveno-pitanje-jedan-posto-hrvata-njih-7.427-prosjecno-na-svojem-racunu-drzi-45-milijuna-kuna-100594 (10.05.2020.)

Jokić B. i Ristić-Dedić, Z. (2019). Cjelovita kurikularna reforma-Izvorne ideje i procesi. Zagreb: Friedrich Ebert Stiftung.

Kahane, A. (2004). Solving Tough Problems: An Open Way of Talking, Listening and Creating New Realities. San Francisco, CA: Berret-Koehler Publishers.

Klette, K. (2018). Individualism and collectivism in Nordic schools: A comparative approach. U: Witoszek, N. i Midttun A. (ur.), Sustainable Modernity: The Nordic Model and Beyond (str. 59-78). London i New York: Routlege.

Kotler, P. i Sarkar C. (2019). The Flywheel of Corruption: Why Our Democracy Isn't Working.

FIXCapitalism.com, 27. travnja 2019. URL: http://fixcapitalism.com/the-flywheel-ofcorruption-why-our-democracy-isnt-working/ (10.05.2020.)

Lakey, G. (2016). Viking Economics: How Scandinavians Got It Right - and How We Can, Too. New York: First Melville House.

Trägårdh, L. (2018). Scaling up solidarity from the national to the global: Sweden as welfare state and moral superpower. U: Witoszek, N. i Midttun A. (ur.), Sustainable Modernity: The Nordic Model and Beyond (str. 79-101). London i New York: Routlege.

Ma. B. (2016). Hrvatski učenici loše su odgovorili na ova pitanja kako biste ih vi riješili? Dnevnik.hr, 6. prosinca 2016. URL: https://dnevnik.hr/vijesti/hrvatska/ 
pisa-2015-hrvatski-ucenici-i-dalje-znatno-ispod-prosjeka-oecd-a---459578.html (10.05.2020.)

Midttun, A. (2018). Challenges to the Nordic work model in the age of globalized digitalization. U: Witoszek, N. i Midttun A. (ur.), Sustainable Modernity: The Nordic Model and Beyond (str. 139-159). London i New York: Routlege.

Ostrom, E. (2014). A Polycentric Approach for Coping with Climate Change. Annals of Economics and Finance, 15(1): 97-134.

Ostrom, E. (2015). Governing the Commons: The evolution of institutions for collective action. Cambridge: Cambridge University Press.

Pavičić, J. (2019). Kako izmjeriti rad nastavnika. Jutarnji list, 7. prosinca 2019. URL: https://www.jutarnji.hr/komentari/kako-izmjeriti-rad-nastavnika/9714241/ $(10.05 .2020$.

Program Ujedinjenih naroda za razvoj (UNDP) (2018). Human Development Indicators and Indices: 2018 Statistical Update. New York: UNDP.

Sachs, J., Schmidt-Traub, G., Kroll, C., Lafortune, G. i Fuller, G. (2019). Sustainable Development Report 2019. New York: Bertelsmann Stiftung i Sustainable Development Solutions Network.

Sanford, C. (2017). The Regenerative Business: Redesign work, Cultivate Human Potential, and Achieve Extraordinary Outcomes. Boston, MA: Nicholas Brealey Publishing.

Scharmer, O. i Kaeufer, K. (2013). Leading from the Emerging Future: from the EgoSystem to Eco-System Economies. San Francisco, CA: Berret-Koehler Publishers.

Senge, M. P. (2001). Peta disciplina: principi i praksa učeće organizacije. Zagreb: Mozaik knjiga.

Sweeney, L. B. (2016). Isn't it Time We All Started "Thinking Like a Bathtub”? Talking About Systems - Linda Booth Sweeney, 17. travnja 2016. URL: http://lindaboothsweeney.net/blog/?cat=11 (10.05.2020.)

Štulhofer, A. i Burić, I. (2015). Je li egalitarni sindrom samo teorijska fantazija? Empirijski hommage Josipu Županovu. Politička misao, 52(3): 7-31.

Transformations Forum (2020). Transformations systems. URL: https://transformationsforum.net/transformations-systems/ (10.05.2020.)

Ujedinjeni narodi (UN) (2020a). Transforming our world: the 2030 Agenda for Sustainable Development https://sustainabledevelopment.un.org/post2015/transformingourworld (10.05.2020.)

Ujedinjeni narodi (UN) (2020b). Voluntary National Reviews. URL: https:// www.ohchr.org/EN/Issues/SDGS/Pages/2020VoluntaryNationalReviews.aspx (10.05.2020.)

Vlada RH (2019). Dobrovoljni nacionalni pregled o provedbi Programa UN-a za održivi razvoj 2030. URL: https://vlada.gov.hr/UserDocsImages/2016/Sjednice/2019/ Srpanj/164\%20sjednica\%20VRH/UN\%20Final/UN\%20-\%20zadnja\%20-\%20 hrvatska\%20verzija.pdf (10.05.2020.)

Vuković, V. (2018). Egalitarizam na periferiji. Arhivanalitika - Ekonomski lab, 2. veljače 2018. URL: http://arhivanalitika.hr/blog/egalitarizam-na-periferiji/ (10.05.2020.) 
Schwab, K. (ur.) (2019). The Global Competitiveness Report 2019. Geneva: World Economic Forum.

Wildfire, M. (2020). False Solutions to Climate Change. Resilience, 1. svibnja 2020. URL: https://www.resilience.org/stories/2020-05-01/false-solutions-to-climate-change-part-1-electricity/ (10.05.2020.)

Wilkinson, R. i Picket K. (2018). The Inner Level, How More Equal Societes Reduce Stress, Restore Sanity and Improve Everyone's Well-Being. New York: Penguin Random House.

Wilson D. S. i Wilson E. O. (2007). Rethinking the Theoretical Foundation of Sociobiology. The Quarterly Review of Biology, 82(4): 327-348.

Wilson, D. S. i Hessen D. O. (2018). Cooperation, competition and multi-level selection: A new paradigm for understanding Nordic model. U: Witoszek, N. i Midttun A. (ur.), Sustainable Modernity: The Nordic Model and Beyond (str. 18-35). London i New York: Routlege.

Wilson D. S. (2019). The origins of Prosocial. Prosocial World. URL: https://www.prosocial.world/post/the-origins-of-prosocial (10.05.2020.)

Witoszek, N., Midtum, A. (2018). Sustainable modernity and the architecture of the "well-being society": Interdisciplinary perspectives. U: Witoszek, N. i Midttun A. (ur.), Sustainable Modernity: The Nordic Model and Beyond (str. 1-17). London i New York: Routlege.

Witoszek N. i Sørensen Ø. (2018). Nordic humanism as a driver of the welfare society. U: Witoszek, N. i Midttun A. (ur.), Sustainable Modernity: The Nordic Model and Beyond (str. 36-58). London i New York: Routlege.

World Value Survey (WVS) (2019). Findings and Insights - Cultural map. URL: http:// www.worldvaluessurvey.org/WVSContents.jsp (10.05.2020.)

Zakon o lokalnim izborima. Narodne novine, 144/12, 121/16, 98/19, 42/20.

Županov, J. (2011). Hrvatsko društvo danas - kontinuitet i promjena. Politička misao, 48(3): 145-163.

Županov, J. (1977). Sociologija i samoupravljanje. Zagreb: Školska knjiga. 


\title{
THE DEVELOPMENT OF A TRANSFORMATIVE SYSTEM IN CROATIA AS A PRECONDITION FOR MEETING SUSTAINABLE DEVELOPMENT GOALS
}

\author{
Miljenko Cimeša and Andreja Pavlović
}

\begin{abstract}
Sustainable development goals (SDGs) represent a very ambitious plan and program for the development of human societies. The warning issued in 2018 by the Intergovernmental Panel on Climate Change on the necessity to reduce $\mathrm{CO}_{2}$ emissions by 45\% by 2030 and achieve carbon neutrality by 2050, shows that there is a limited time period to implement these goals. This paper examines Croatia's readiness to implement SDGs. Our main hypothesis is that Croatia is not ready as the implementation of SDGs would require a number of transformative changes at all levels and in all segments of Croatian society. The main aim of this paper is to encourage discussion and activities directed toward the promotion of forms and culture of cooperation as a critical precondition for the implementation of SDGs in Croatia. The paper relies on a conceptual analysis from diverse scientific areas, with the emphasis on articles that describe the so-called "Nordic model" as well as the specific situation in Croatia. We tried to determine the underlying causes to existing problems by relying on systematic thinking tools in the interpretation of the results. The research confirmed our initial hypothesis that Croatia is not yet ready for the implementation of SDGs. Preliminary assessment of the situation in Croatia revealed the absence of a commonly accepted vision of society as well as the lack of prosocial behavior in all segments and at all levels of the society. Therefore, the implementation of SDGs in Croatia, under such circumstances and within the given timeframe, truly requires transformative social changes. This is then posed as a moral obligation of the present generation of leaders to future generations.
\end{abstract}

Key words: sustainable development goals, transformative changes, Nordic model, systematic thinking, culture of cooperation

\section{ENTWICKLUNG DES KROATISCHEN TRANSFORMATIONSSYSTEMS ALS VORAUSSETZUNG FÜR DIE DURCHFÜHRUNG DER ZIELE DER NACHHALTIGEN ENTWICKLUNG}

\begin{abstract}
Zusammenfassung
Die Ziele der nachhaltigen Entwicklung (englische Abkürzung SDGs) stellen einen sehr ambitionierten Entwicklungsplan der menschlichen Gesellschaft dar. Die Warnung des Zwischenstaatlichen Ausschusses für Klimaänderungen aus dem Jahr 2018 über die Notwendigkeit, den $\mathrm{CO}_{2}$-Ausstoß bis 2030 um 45 Prozent zu verringern und bis 2050 eine $\mathrm{CO}_{2}$-Neutralität zu erreichen, weist darauf hin, dass die Zeit zur Erreichung dieser Ziele beschränkt ist. Die Forschungsfrage im Brennpunkt dieser Arbeit bezieht sich auf die Bewertung der Bereitschaft von Kroatien, die SDGs durchzuführen. In der Arbeit wird die These geprüft, dass Kroatien zur Durchführung von SDG nicht bereit ist. Die Durchführung von SDG setzt voraus, dass transformative Änderungen auf allen Ebenen und in allen Segmenten der kroatischen Gesellschaft realisiert sind. Das Ziel der Arbeit ist, die zur Entwicklung einer Struktur (und Kultur) der Zusammenarbeit führenden Diskussionen und Aktivitäten anzuregen, denn dies ist eine Voraussetzung für die Verwirklichung von SDGs in Kroatien. In der Arbeit bedienen wir uns der konzeptionellen Analyse der Werke aus verschiedenen Wissenschaftsgebieten, der Analyse der Arbeiten über die Struktur und das Funktionieren des "nordischen Modells", sowie der Analyse der Arbeiten über den Zustand in Kroatien. Bei der Auslegung der Befunde benutzten wir die systems thinking tools, die den tiefsten Einblick in die Ursachen der bestehenden Probleme ermöglichen. Durch die Forschung wurde die Eingangsthese bestätitgt, dass Kroatien nicht auf
\end{abstract}

Miljenko Cimeša und Andreja Pavlović 
die Durchführung von SDG vorbereitet ist. Die vorläufige Bewertung des Zustands in Kroatien hat auf eine nicht bestehende allgemein akzeptierte Vision der Gesellschaft hingewiesen, sowie auf das Fehlen eines prosozialen Verhaltens in allen Segmenten und auf allen Ebenen der Gesellschaft. Unter solchen Umständen setzt die Durchführung von SDG u Kroatien im vorgegebenen Zeitrahmen wirklich voraus, dass transformative Änderungen in Gang gesetzt werden. Das ist die wichtigste moralische Verpflichtung der jetzigen Generation der Leader den zukünftigen Generationen gegenüber.

Schlüsselwörter: Ziele der nachhaltigen Entwicklung, transformative Veränderungen, nordisches Modell, systematisches Denken, Kultur der Zusammenarbeit 